\title{
PERLINDUNGAN HUKUM TERHADAP TENAGA KERJA ASING YANG BEKERJA DI INDONESIA*
}

\author{
OLEH : \\ Ida Ayu Mirah Bijas Swari ${ }^{* *}$ \\ I Wayan Novy Purwanto*** \\ Program Kekhususan Hukum Bisnis \\ Fakultas Hukum Universitas Udayana
}

\begin{abstract}
ABSTRAK
Penggunaan tenaga kerja asing saat ini masih banyak dan sulit dihindarkan dikarenakan beberapa faktor, yang diantaranya dalam kegiatan penanaman modal dalam rangka pembangunan nasional dan untuk penguasaan dan alih teknologi sebagai proses berlanjut dan berkesinambungan sehingga memungkinya adanya penggunaan tenaga kerja asing,masih minimnya tenaga kerja Indonesia yang ahli dan terampil untuk menggantikan tenaga kerja asing. kurang tersedianya tenaga kerja Indonesia yang memenuhi persyaratan untuk melakukan pekerjaan yang tersedia,penggunaan mesin-mesin berteknologi canggih yang memiliki resiko tinggi jika yang menangani bukan dari tenaga ahli,semakin menjamurnya usaha-usaha yang membutuhkan tenaga kerja warga Negara asing. Di Indonesia telah memiliki aturan hukum yang mengatur tentang tenaga kerja asing, baik bagaimana perlindungan hukum bagi tenaga kerja asing atas dana kompensasi penggunaan tenaga kerja asing,apa saja sanksi hukum bagi pemberi kerja yang tidak membayar dana kompensasi penggunaan tenaga kerja asing. Jenis penulisan yuridis normatif dimana pendekatan dilakukan melalui menelaah terori-teori, asasasas, peraturan, konsep-konsep.Sehingga perlindungan hukum bagi tenaga kerja asing ialah mewajibkan pemberi kerja membayar dana kompensasi penggunaan tenaga kerja asing, dan sanksi
\end{abstract}

${ }^{*}$ Penulisan Karya Ilmiah yang berjudul Perlindungan Hukum Terhadap Tenaga Kerja Asing Yang Bekerja Di Indonesia ini bukan merupakan ringkasan skripsi namun di luar skripsi.

** Ida Ayu Mirah Bijas Swari merupakan Mahasiswa Fakultas Hukum Universitas Udayana Korespodensi idaayumirahbijass@gmail.com

*** I Wayan Novy Purwanto merupakan Dosen Fakultas Hukum Universitas Udayana, Korespodensi novypurwanto17@gmail.com 
administrative yang dapat dikenakan bagi pemberi kerja yang tidak membayar dana kompensasi penggunaan tenaga kerja asing.

\title{
Kata Kunci : Perlindungan Hukum, Tenaga Kerja Asing
}

\begin{abstract}
The use of foreign workers is still a lot and is difficult to avoid because of several factors, which include investment activities in the context of national development and for mastering and transferring technology as a continuous and continuous process so that it allows the use of foreign workers, the lack of Indonesian workers expert and skilled to replace foreign workers. lack of availability of Indonesian workers who meet the requirements to do the available work, the use of sophisticated technology machines that have a high risk if those who handle not from experts, the more mushrooming of businesses that require foreign workers. In Indonesia, it has legal rules governing foreign workers, both how the legal protection for foreign workers for compensation funds for the use of foreign workers, what are the legal sanctions for employers who do not pay compensation funds for the use of foreign workers. The type of normative juridical writing in which the approach is carried out through examining theories, principles, rules, concepts. So that legal protection for foreign workers is to require employers to pay compensation funds for the use of foreign workers, and administrative sanctions that can be imposed on employers who do not pay compensation funds for the use of foreign workers.
\end{abstract}

\section{PENDAHUluan}

\section{$1.1 \quad$ Latar Belakang}

Saat ini Negara Indonesia berada dalam era globalisasi yang sangat membawa pengaruh pada majunya suatu perkembangan yang diantaranya baik pada bidang teknologi maupun informasi yang terus-menerus akan mengalami pembaharuan. Selain itu Indonesia juga saat ini sedang menyelenggarakan segala upaya 
untuk membangun perekonomian ke arah yang lebih baik.Melimpahnya sumber daya alam yang dimiliki Indonesia seharusnya menjadi sesuatu yang menguntungkan bagi diIndonesia.Hanya saja Indonesia masih masih berada dalam keterbatasan pada tersedianya tenaga ahli yang memiliki keahlian dan kemampuan dalam hal mengolah sumber daya alam yang ada di Indonesia.

Melihat dari besarnya jumlah sumber daya manusia yang dimiliki oleh Indonesia. Seharusnya bangsa Indonesia mampu mengolah sumber daya alam yang dimiliki secara mandiri, namun karena sumber daya manusia yang dimiliki sebagian besar masih belum memenuhi kriteria yang diinginkan oleh pemberi kerja, terlebih lagi karena kualitas dan keahlian juga jenjang pendidikan yang masih rendah mengakibatkan ketidakmapuan tenaga kerja tersebut dalam hal mengolah sumber daya alam yang ada. Hal ini akan menghambat pembangunan perekonomian di Indonesia.

Seiring dengan meningkatnya pembangunan nasional dalam segala sektor nasional, melatarbelakangi terjadinya problematika khususnya di bidang ketenagakerjaan yang segi dimensi ekonomis.Sehingga membuat setiap perusahaa sangat membutuhkan tenaga ahli yang memiliki kemampuan dan menguasai ilmu pengetahuan didalam lingkungan perusahaanya.

Terciptanya perdagangan global yang diaplikasikan dengan perdagangan bebas waktu tahun 1995 yang dipelopori oleh WTO, menciptakan era perdagangan ditingkat regional menciptakan era perdagangan bebas yang menghasilkan blok-blok perdagangan ditingkat regional. Menyebabkan terjadinya arus perdagangan barang dan jasa menjadi borderless, sehingga perdagangan mengalami perubahan yang mendasar. 
Pertumbuhan globalisasi tersebut mendorong tumbuhnya dinamika mengalirnya dana permodalan keberbagai penjuru dunia termasuk di Indonesia terdapat para pemodal asing yang menananmkan dananya di Indonesia untuk berinvestasi. Oleh karena itu Indonesia membutuhkan tenaga kerja asing lantaran terkait dengan kegiatan investasi, sebab memerlukan tenagatenaga terampil yang sangat terpecaya dalam hal kegiatan pengelolaan dana yang telah ditanamkan di Indonesia.

Apalagi saat ini Industri mulai bergeser kearah digital, dimana tenaga kerja lokal Indonesia belum mampu memanfaatkan secara maksimal.Sehingga dibutuhkan tenaga kerja asing untuk membantu membimbing tenaga kerja lokal agar bisa lebih berkembang.

Penggunaan tenaga kerja asing saat ini masih banyak dan sulit dihindarkan, dikarenakan beberapa faktor, yang diantaranya sebagai berikut

1. Kegiatan penanaman modal dalam rangka pembangunan nasional dan untuk penguasaan dan alih teknologi sebagai proses berlanjut dan berkesinambungan sehingga memungkinya adanya penggunaan tenaga kerja asing

2. Masih minimnya tenaga kerja Indonesia yang ahli dan terampil untuk menggantikan tenaga kerja asing

3. Kurang tersedianya tenaga kerja Indonesia yang memenuhi persyaratan untuk melakukan pekerjaan yang tersedia

4. Pegunaan mesin-mesin berteknologi canggih yang memiliki resiko tinggi jika yang menangani bukan dari tenaga ahli. 
5. Semakin menjamurnya usaha-usaha yang membutuhkan tenaga kerja warga Negara asing. ${ }^{1}$

Mempekerjakan tenaga kerja asing mendatangkan keuntungan yang sangat besar juga bagi tenaga kerja Indonesia melalui alih teknologi dan ahli keahlian yang akan berdampak pada meningkatnya mutu dari tenaga kerja Indonesia.Hal tersebut menjadi peluang bagi Indonesia agar bisa bersinar seperti NegaraNegara maju.

Tenaga kerja asing juga dapat semaksimal mungkin bisa dimanfaatkan bagi perusahaan-perusahaan untuk memahami sistem produksi dan langkah-langkah manajemen yag dimiliki dari Negara-negara lain yang sudah lebih maju dalam historis universal. Praktis semua Negara sebelumnya berkembang kemudian mampu menjadi Negara maju diawali dari investasi asing.

Dalam mendukung proses konstruksi investasi sangat berperan dan membutuhkan tenaga kerja asing. Salah satu yang hal yang menjadi perhatian adalah mengenai pembayaran Dana Kompensasi Penggunaan Tenaga Kerja Asing yang mewajibkan pemberi kerja di setiap perusahaan yang mempekerjakan Tenaga Kerja Asing.

\subsection{Rumusan Masalah}

Dari uraian diatas yang telah disampaikan, maka permasalahan yang akan saya untuk dibahas :

1. Bagaimana perlindungan hukum bagi tenaga kerja asing atas dana kompensasi penggunaan tenaga kerja asing ?

${ }^{1}$ Syarif H.S, Pedoman Penggunaan Tenaga kerja Asing di Indonesia dan Peraturan-Peraturannya, Sinar Grafika,Jakarta,2003.h.17-18 
2. Apa saja sanksi hukum bagi pemberi kerja yang tidak membayar dana kompensasi penggunaan tenaga kerja asing?

\subsection{Tujuan Penulisan}

Adapun tujuan penulisan yang ingin dicapai disini mengenai:

1. Untuk mengetahui bagaimana perlindungan hukum terhadap tenaga kerja asing atas dana kompensasi penggunaan tenaga kerja asing.

2. Untuk mengetahui apa saja sanksi hukum bagi pemberi kerja yang tidak membayar dana kompensasi penggunaan tenaga kerja.

\section{II.ISI MAKALAH}

\subsection{Metode Penulisan}

Jenis Penulisan Yuridis Normatif, yakni pendekatan diawali dengan cara tahap menelaah teori-teori, asas-asas, peraturanperaturan dan terakhir konsep-konsep. Penelitian ilmiah yang dijelaskan dalam metode hukum doktriner/penelitian perpustakaan.Penelitian ini didasarkan aturan-aturan tertulis berkaitan erat terhadap perpustakaan sebagai sumber bahan hukum, bersifat sekunder.Penelitian hukum ini yaitu suatu bentuk kegiatan ilmiah, yang berdasarkan pada metode, sistematika, dan pemikiran tertentu yang bertujuan untuk mempelajari suatu serta gejala hukum dengan menganalisanya. ${ }^{2}$

2 Soerjono, Pengantar Penelitian Hukum, Universitas Indonesia, Jakarta 1986, h.43 


\subsection{Hasil Dan Pembahasan}

\subsubsection{Perlindungan hukum bagi tenaga kerja asing atas dana kompensasi penggunaan tenaga kerja asing}

Menjadi Negara hukum sebagaimana yang termaktub dalam Undang-Undang Negara Republik Indonesia 1945, semakin menegasskan kuatnya dasar hukum dan dijadikan sebagai pedoman Negara.Dalam artian terwujudnya tujuan yakni kepastian hukum, mengupayakan berlaku adil, legitimasi demokrasi tuntutan pikiran baikm.Oleh karenanya mengharuskan segala kegiatan berlandaskan dengan hukum di Indonesia.

Sebagai Negara hukum, Indonesia harus melakukan pemenuhan perlindungan hukum kepada semua subjek hukum yang berada di wilayah Negara Republik Indonesia, diantaranya yang berkaitan dengan tenaga kerja asing yang bekerja di Indonesia.Karena hukum sudah sepatutnya menjamin perlindungan hukum bagi semua orang.

Berdasarkan pasal 47 (1) Undang-Undang No 13 tahun 2003 tentang Ketenagakerjaan yang berbunyi Pemberi kerja berkewajiban untuk melakukan pembayaran kompensasi kepada setiap tenaga kerja asing yang dipekerjaannya. Dalam pasal ini mengatur tentang kewajiban membayar kompensasi.

Dana kompensasi penggunaan tenaga kerja asing dana yang harus dibayar setiap perusahaan yang menggunakan tenaga kerja asing. Syarat dana kompensasi penggunaan tenaga kerja asing adalah mengisi formulir yang disediakan, sesuai data tenaga kerja asing dalam KITAS dan Paspor. ${ }^{3}$ Dalam pasal 32 Peraturan Menteri Tenaga Kerja dan Transmigrasi No 12 tahun 2013 tentang Tata Cara Penggunaan Tenaga Kerja Asing mengatur mengenai kewajiban pembayaran dana kompensasi tenaga kerja asing oleh

3 Hidayat Muharam, Hukum Ketenagakerjaan serta Pelaksanaannya di Indonesia, Citra Aditya Bakti, Jakarta, 2006,h.107 
setiap pemberi kerja juga mengatur tentang ketentuan besaran kompensasi penggunaan tenaga kerja asing, dengan besaran jumlahnya yaitu 100 dollar amerika perjabatan/perbulan. ${ }^{4}$ Untuk setiap tenaga kerja asing yang dibayarkan dimuka. Apabila masa kontraknya 12 bulan dengan tenaga kerja tersebut,maka jumlah yang harus dibayar melalui yang ditunjuk oleh menteri sebesar 1200 usd.

Pada Peraturan Menteri Ketenagakerjaan Republik Indonesia Nomor 35 tahun 2015 Tentang Perubahan Atas Peraturan Menteri Ketenagakerjaan Nomor 16 tahun 2015 tentang Tata Cara Penggunaan Tenaga Kerja Asing dalam pasal 40 ayat (1), (3), (4),(5) mengatur mengenai Pembayaran dana kompensasi penggunaan tenaga kerja asing yang berbunyi :

(1) DKP-TKA sebagaimana dimaksud dalam pasal 38 ayat (1) huruf a ditetapkan sebesar US \$100 (seratus dollar Amerika per-jabatan/ bulan untuk setiap tenaga kerja asing yang dibayarkan di muka .

(3) pemberi kerja tenaga kerja asing yang mempekerjakan tenaga kerja asing kurang dari 1 ( satu bulan) wajib membayar dana kompensasi penggunaan tenaga kerja asing sebesar satu bulan penuh.

(4) Formulir pembayaran dana kompensasi penggunaan tenaga kerja asing sebagaimana dimaksud pada aya (1) memuat :

a. nama pemberi kerja tenaga kerja asing

b. nama tenaga kerja asing

c. jabatan tenaga kerja asing

d. jangka waktu penggunaan tenaga kerja asing

e. jumlah yang dibayarkan

4 Widodo Suryandono, Tenaga kerja Asing : Analisis Politik Hukum, Yayasan Pustaka Obor Indonesia, Jakarta,2017, h. 85 
(5) Pembayaran dana kompensasi penggunaan tenaga kerja asing sebagaimana dimaksud pada ayat (1) dilakukan oleh pemberi kerja tenaga kerja asing dan disetorkan pada rekening dana kompensasi penggunaan tenaga kerja asing pada bank pemerintah yang ditunjuk melalui Menteri.

Jika tenaga kerja asing bekerja kurang dari satu bulan, maka wajib membayar dana kompensasi sebesar 1 (satu) bulan penuh.Ketentuan ini juga diatur dalam pasal 15 Peraturan Presiden Nomor 20 tahun 2018 tentang Penggunaan Tenaga Kerja Asing yang berbunyi :

(1) Pemberi tenaga kerja asing wajib membayar dana kompensasi penggunaantenaga kerja asing atas setiap tenaga kerja asing yang dipekerjakan setelah menerima notifikasi

(2) Pembayaran dana kompensasi penggunaan tenaga kerja asing sebagaimana dimaksud pada ayat (1) dilakukan melalui bank yang ditunjuk oleh Menteri

(3) Pembayaran dana kompensasi penggunaan tenaga kerja asing oleh pemberi kerja tenaga kerja asing merupakan penerimaan Negara bukan pajak.

Selanjutnya dalam pasal 24 (1) Peraturan Presiden Nomor 20 tahun 2018 tentang Penggunaan Tenaga Kerja Asing mengatur mengenai pembayaran dana kompensasi penggunaan tenaga kerja asing dilakukan setiap tahun sesuai dengan jangka waktu tenaga kerja bekerja di wilayah Indonesia. Dana Kompensasi Penggunaaan Tenaga Kerja Asing ini menjadi suatu syarat yang mutlak pengurusan KITAS penangguhan. ${ }^{5}$ Dengan maksud supaya perusahaan patuh terhadap ketentuan bahwa KITAS penangguhan diproses sehubungan menunggu penyelesaian selesainya Ijin Mempekerjakan Tenaga Kerja Asing (IMTA) h. 195

5 Teguh Hambudi, Professional General Affair,Visi Media, Jakarta, 2015, 
Banyaknya perusahaan pemberi kerja yang melakukan KITAS penangguhan namun kenyataannya perusahaan pemberi kerja tersebut tidak jadi memperpanjang dokumen perijinan dan akhirnya memulangkan tenaga kerja asing yang dimaksud ke Negara asal.Selanjutnya sebagai persyaratan mutlak dalam pengajuan Rekomendasi Alih Jabatan Tenaga Kerja Asing.Dalam hal ini memiliki maksud supaya perusahaan pemberi kerja disiplin dalam melengkapi dokumen perijinan bagi tenaga kerja asing yang dipekerjakan.

Dana kompensasi penggunaan tenaga kerja asing sebagai wujud perlindungan hukum bagi tenaga kerja asing karena telah diatur dalam peraturan perundang-undangan yang berlaku di Indonesia, yang memberikan kewajiban bagi setiap pemberi kerja menggunakan tenaga kerja asing untuk melakukan pembayaran dana tersebut. Dana kompensasi sebagai bentuk apresiasi dari pemberi kerja kepada tenaga kerja asing. Dengan dana kompensasi, tenaga kerja asing berguna dalam hal meminimalisir terjadinya kesulitan dalam keuangan bagi tenaga kerja asing.

\subsubsection{Sanksi Hukum Bagi Pemberi Kerja yang tidak membayar dana kompensasi penggunaan tenaga kerja asing}

Dalam terjadinya pelanggaran terhadap hukum ketenagakerjaan, tidak luput dari ancaman sanksi atau hukuman sama seperti pelanggaran hukum lainnya. Hukum ketenagakerjaan terdapat beberapa pasal-pasal yang mengatur mengenai sanksi/hukuman yang dapat diberikan kepada seseorang yang melakukan pelanggaran.Dan hal tersebut tergantung dari jenis-jenis pelanggaran yang dilakukan dalam hukum ketenagakerjaan.

Sanksi adalah suatu langkah hukuman yang diberikan oleh Negara atau kelompok tertentu sebagai akibat dari adanya suatu 
pelanggaran yang dilakukan oleh seseorang atau kelompok.Dengan tujuan agar oknum yang melakukan suatu pelanggaran menjadi sadar akan perbuatannya dan jera sehingga tidak akan melakukan kembali kesalaha yang telah diperbuat.

Dalam hubungan industrial terdapat tiga jenis sanksi yang dapat dikenakan jika terjadi suatu pelanggaran, sanksi-sanksi tersebut diantaranya berupa sanksi administratif, sanksi perdata, sanksi pidana. Pada pasal 183,pasal 184,pasal 185,pasal 186,pasal 187,pasal 188, pasal 189 dalam Undang-Undang Nomor 13 tahun 2003 tentang Ketenagakerjaan telah mengatur ketentuan mengenai sanksi pidana, diantaranya sanksi pidana penjara, sanksi pidana kurungan, serta denda berupa uang. Kemudian dalam pasal 190 Undang-Undang Nomor 13 tahun 2003 tentang Ketenagakerjaan mengatur ketentuan tentang sanksi administratif yang salah satunya pelanggaran atas wajib membayar kompensasi bagi setiap tenaga kerja asing yang dipekerjakan.

Maka bagi setiap tenaga kerja asing yang tidak dibayarkan dana kompensasinya dalam artian tidak dilakukannya pembayaran dana kompensasi oleh pemberi kerja merupakan suatu bentuk pelanggaran hukum yang dilakukan oleh pemberi kerja.Dalam hal ini sanksi administrative yang dapat dijatuhkan kepada pemberi kerja.

Sanksi administratif pada dasarnya produk penguasa yang bersifat umum, yang dipakai oleh penguasa dalam merespon atas perbuatan tidak taatnya seseorang pada suatu keharusan yang ada dalam peraturan.Sanksi administrative yang dapat diberikan kepada pemberi kerja yang tidak membayar dana kompensasi penggunaan tenaga kerja asing dapat berupa teguran, peringatan tertulis, pembatasan kegiatan usaha, pembatalan persetujuan, 
pembatalan pendaftaran, penghentian sementara sebagian atau seluruh alat produksi, serta pencabutan ijin. ${ }^{6}$

Sebagaimana yang telah diatur dalam Undang-Undang Nomor 13 tahun 2003 tentang Ketenagakerjaan pada pasal 190 ayat (1) Menteri atau pejabat yang ditunjuk mengenakan sanksi administrative atas pelanggaran ketentuan-ketentuan sebagaimana diatur dalam pasal 5 , pasal 6 , pasal 15 , pasal 25 , pasal 38 ayat (2), pasal 45 ayat (1), pasal 47 ayat (1), pasal 48, pasal 87, pasal 106 pasal 126 aya (3) dan pasal 160 ayat (1) dan ayat (2) Undang -undang ini serta peraturan pelaksanaannya. Kemudian dalam ayat (2) sanksi administrative sebagaimana dimaksud dalam ayat (1) berupa:
a. teguran
b. peringatan tertulis
c. pembatasan kegiatan usaha
d. pembekuan kegiatan usaha
e. pembatalan persetujuan
f. pembatalan pendaftaran
g. penghentian sementara sebagian atau seluruh alat produksi
h. pencabutan ijin

Berdasarkan pada pasal sebagaimana yang telah dijelaskan diatas, maka apabila bagi pemberi kerja yang tidak membayar dana kompensasi penggunaan tenaga kerja asing yang merupakan suatu kewajiban bagi setiap pemberi kerja yang mempekerjakan tenaga kerja asing, maka pemberi kerja tersebut dapat dikenakan sanksi administrasi. Teguran tertulis merupakan peringatan bagi pemberi kerja atas pelanggaran hukum yang telah dilakukan baik itu tidak membayar dana kompensasi penggunaan tenaga kerja asing.

${ }^{6}$ Much Nurachmad, Cara Menghitung Upah Pokok, Pesangon \& Dana Pensiun untuk Pegawai dan Perusahaan, Visi Media, Jakarta, 2009,h. 108 
Pembatasan kegiatan usaha adalah pembatasan kapasitas produksi berupa barang maupun jasa dalam waktu tertentu dan/ atau penundaan pemberian izin usaha disalah satu atau beberapa lokasi bagi perusahaan yang memiliki proyek dibeberapa lokasi.Penghentian sementara sebagian atau seluruh alat produksi dalam artian tidak menjalankan sebagian atau seluruh alat produksi berupa barang maupun jasa dalam waktu tertentu. Pembekuan kegiatan usaha berarti menghentikan seluruh proses produksi barang dan jasa perusahaan dalam waktu tertentu. 


\section{PENUTUP}

\subsection{Kesimpulan}

1. Perlindungan hukum bagi tenaga kerja atas dana kompensasi penggunaan tenaga kerja asing dapat dilihat dalam peraturan hukum ketenagakerjaan yang berlaku di Indonesia terkait penggunaan tenaga kerja asing pada intinya memuat ketentuan yang mewajibkan setiap pemberi kerja yang menggunakan tenaga kerja asing untuk melakukan pembayaran atas dana kompensasi penggunaan tenaga kerja asing.

2. Sanksi yang dapat dijatuhkan kepada pemberi kerja yang tidak membayar dana kompensasi penggunaan tenaga kerja asing adalah sanksi administrative yang berupa teguran, peringatan tertulis, pembatasan kegiatan usaha, pembatalan persetujuan, pembatalanpendaftaran, penghentian sementara sebagian atau seluruh alat produksi, serta pencabutan ijin. Sebagaimana yang telah diatur dalam pasal 190 ayat (1) dan (2) Undang-Undang Nomor 13 tahun 2003 tentang Ketenagakerjaan .

\subsection{Saran}

1. Terhadap perlindungan hukum bagi tenaga kerja asing atas dana kompensasi penggunaan tenaga kerja asing diharapkan dapat diberikan semaksimal mungkin sesuai dengan ketentuan peraturan yang berlaku dan khususnya bagi pemberi kerja untuk wajib mengikuti setiap aturan hukum yang khususnya mengatur mengenai dana kompensasi penggunaan tenaga kerja asing.

2. Seharusnya diberlakukan sanksi yang lebih berat bagi pemberi kerja yang tidak membayar dana kompensasi penggunaan tenaga kerja asing ini bertujuan agar 
memberikan efek jera bagi pemberi kerja sehingga pemberi kerja tersebut tidak akan mengulangi perbuatannya. 


\section{DAFTAR PUSTAKA}

\section{LITERATURE :}

Hidayat Muharam, Hukum Ketenagakerjaan serta Pelaksanaannya di Indonesia, Citra Aditya Bakti, Jakarta, 2006.

Much Nurachmad, Cara Menghitung Upah Pokok, Pesangon \& Dana Pensiun untuk Pegawai dan Perusahaan, Visi Media, Jakarta, 2009.

Teguh Hambudi, Professional General Affair,Visi Media, Jakarta, 2015.

Widodo Suryandono, Tenaga kerja Asing : Analisis Politik Hukum, Yayasan Pustaka Obor Indonesia, Jakarta,2017

Syarif H.S, Pedoman Penggunaan Tenaga kerja Asing di Indonesia dan Peraturan-Peraturannya, Sinar Grafika,Jakarta,2003.

Soerjono, Pengantar Penelitian Hukum, Universitas Indonesia, Jakarta 1986,

\section{KARYA ILMIAH :}

Eka Krisna Yanti, Supasti 2018, "Prinspip Non Diskriminasi Tenaga Kerja Asing Dalam Kerangka GATS: Dimensi Kepariwisataan" Jurnal Hukum Magister Hukum Universitas Udayana,Bali .

Yoga Dharma, Wiratni Darmadi, 2015, "Pengaruh Penerapan Prinsip Non Diskriminasi Penanaman Modal Di Indonesia." Jurnal Hukum Kertha Semaya Fakultas Hukum Universitas Udayana, Bali

\section{PERATURAN PERUNDANG-UNDANGAN}

Undang-Undang Negara Republik Indonesia 1945

Undang-Undang Nomor 13 Tahun 2004 Tentang Ketenagakerjaan

Peraturan Menteri Tenaga Kerja dan Transmigrasi No 12 tahun 2013 tentang Tata Cara Penggunaan Tenaga Kerja Asing 
Peraturan Menteri Ketenagakerjaan Republik Indonesia Nomor 35 tahun 2015 Tentang Perubahan Atas Peraturan Menteri Ketenagakerjaan Nomor 16 tahun 2015 tentang Tata Cara Penggunaan Tenaga Kerja

Peraturan Presiden Nomor 20 tahun 2018 tentang Penggunaan Tenaga Kerja Asing 